\title{
Implementation Plan: JASPER Management Prestart Review (Surrogate Material Experiments)
}

W. E. Cooper

September 29, 2000

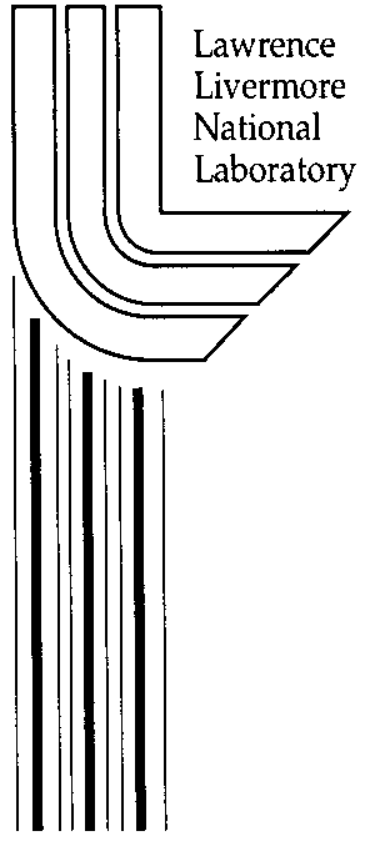




\section{DISCLAIMER}

This document was prepared as an account of work sponsored by an agency of the United States Government. Neither the United States Government nor the University of California nor any of their employees, makes any warranty, express or implied, or assumes any legal liability or responsibility for the accuracy, completeness, or usefulness of any information, apparatus, product, or process disclosed, or represents that its use would not infringe privately owned rights. Reference herein to any specific commercial product, process, or service by trade name, trademark, manufacturer, or otherwise, does not necessarily constitute or imply its endorsement, recommendation, or favoring by the United States Government or the University of California. The views and opinions of authors expressed herein do not necessarily state or reflect those of the United States Government or the University of California, and shall not be used for advertising or product endorsement purposes.

Work performed under the auspices of the U. S. Department of Energy by the University of California Lawrence Livermore National Laboratory under Contract W-7405-Eng-48.

This report has been reproduced

directly frorn the best available copy.

Available to DOE and DOE contractors from the

Office of Scientific and Technical Information

P.O. Box 62, Oak Ridge, TN 37831

Prices available from (423) 576-8401

http://apollo.osti.gov/bridge/

Available to the public from the National Technical Information Service

U.S. Department of Commerce 528.5 Port Royal Rd., Springfield, VA 22161

http://www.ntis.gov/

OR

Lawrence Livermore National Laboratory

Technical Information Department's Digital Library

http://www.llnl.gov/tid/Library.html 


\section{Implementation Plan: JASPER Management Prestart Review (Surrogate-Material Experiments)}

September 29, 2000

Prepared by:

Wilson E. Cooper

Date

Management Prestart Review Team Leader

Approved by:

Lawrence A. Nattrass

Date

Nevada Experiments and Operations Program Leader Defense and Nuclear Technologies Directorate

Lawrence Livermore National Laboratory 


\section{Contents}

1. Introduction and Background .................................................................... 1

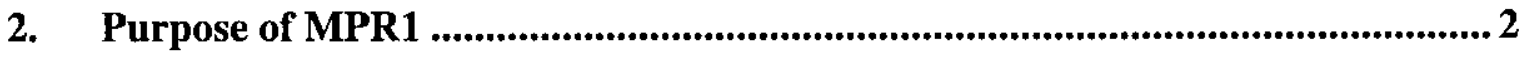

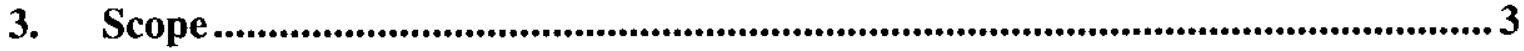

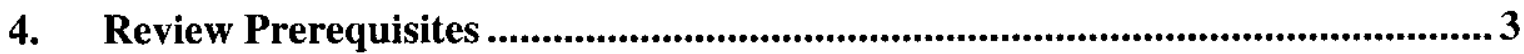

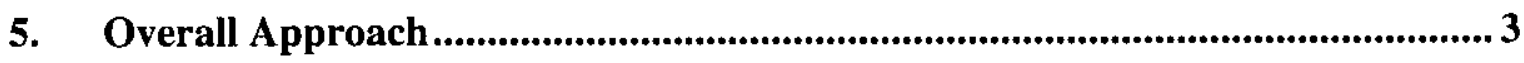

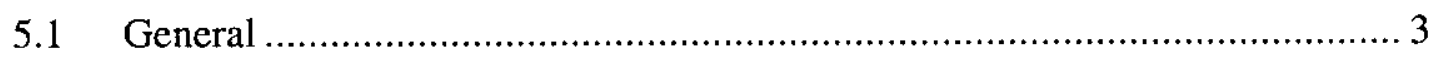

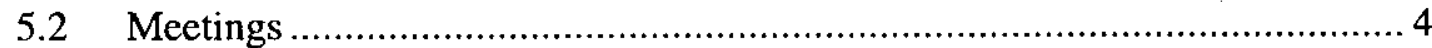

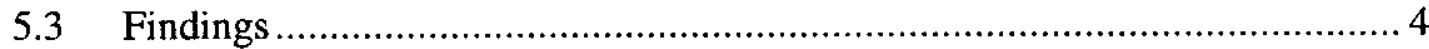

6. Review Preparations .................................................................................... 4

7. Programmatic Review Process ..................................................................5 5

7.1 JASPER Elements Subject to Review ............................................. 5

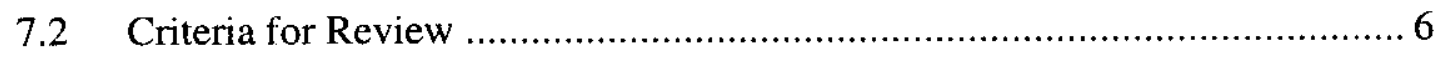

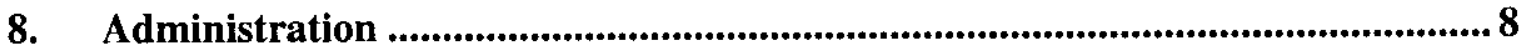

9. Reporting and Resolutions.......................................................................... 8

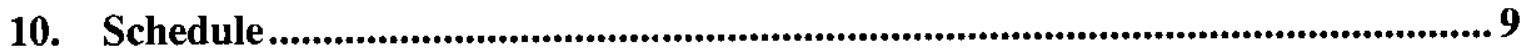

Appendix A. Review Documentation List ............................................................... 10

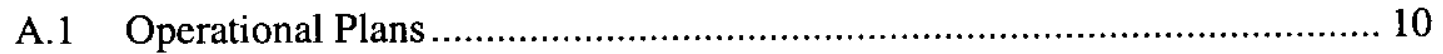

A.2 Technical Operating Procedures .................................................... 11

A.3 Administrative Procedures ......................................................... 12

A.4 System Design Descriptions ....................................................... 13 


\section{Introduction and Background}

Able Site is located $24 \mathrm{~km}$ northwest of Mercury on the Nevada Test Site. The Nevada Test Site is approximately $105 \mathrm{~km}$ northwest of Las Vegas, NV. Major facilities at Able Site include Buildings 5100, 5180, and 5191.

Building 5100 is a single-story building made of reinforced masonry blocks. The building consists of four operational rooms: breech room, SCC room, control room, and laser room. It also contains a mechanical equipment room and communications room. The breech room contains the gun breech and pump tube, a piston assembly area, and hardware storage areas. The SCC room contains the gun's acceleration reservoir (AR), launch tube, and SCC. Diagnostic equipment and power supplies are located in the SCC room. The control room contains diagnostics and control racks; and the laser room contains two laser systems, diagnostics racks, and an optics work table. Building 5100 has been extensively modified and upgraded during construction activities. The building is equipped with a fire detection and alarm system, automatic fire suppression system, hydrogen and radiological monitoring and alarm systems, and a lightning protection system.

Building 5180 is a heavily reinforced concrete bunker covered by $0.9 \mathrm{~m}$ of soil. It will be used to assemble the primary target chamber (PTC) prior to installation into the gas gun in Building 5100. It is equipped with a fire detection and alarm system, a continuous air monitor (stand-alone radiological monitoring), and a lightning protection system.

Building 5191 is an engineered metal-frame structure on a concrete slab foundation. It houses a small machine shop, a film-reading room, and a darkroom. This building will be used to fabricate the gas gun projectiles. It is equipped with a fire detection and alarm system and an automatic fire suppression system.

Significant external interfaces for the JASPER site include the electrical system, wastewater system, communications systems, and water supply system, which provides both potable and fire-protection water. Support services, which are provided on the Nevada Test Site, include medical, emergency response (NTS Fire Department), radiation protection, industrial hygiene, and waste management.

Although JASPER will ultimately be used for actinide research, the start-up process requires system demonstration using surrogates in place of the actinide targets. LLNL Nevada Experiments and Operations (N) Program has established a Management Prestart Review (MPR) team to determine the readiness of the JASPER personnel and facilities to initiate surrogate-material experiments. A second MPR will be conducted before actinide experiments are executed. This document addresses implementation requirements for only the first MPR. This first review coincides with the completion of authorization-basis documents and physical subsystems, which have undergone appropriate formal engineering design reviews. This MPR will affirm the quality of those reviews, their findings/resolutions, and will look most closely at systems integration requirements and demonstrations that will have undergone technical acceptance reviews before this formal MPR action. Closure of MPR findings will finalize requirements for a DOE/NV Real 
Estate/ Operations Permit (REOP) for surrogate-material experiments. Upon completion of that experiment series and the establishment of capabilities for incorporating special nuclear material (SNM) into future experiments, the team will convene again as part of the process of authorizing those activities.

A summary of the review schedule is provided below.

\begin{tabular}{|l|l|l|}
\hline \multicolumn{1}{|c|}{ Review } & \multicolumn{1}{|c|}{ Abbreviation } & \multicolumn{1}{c|}{ Completion date } \\
\hline Completion of system integration tests & & $10 / 20 / 00$ \\
\hline MPR for surrogate-material experiments & JASPER MPR1 & $10 / 18 / 00$ \\
\hline MPR for SNM experiments & JASPER MPR2 & $4^{\text {th }}$ Quarter FY 01 \\
\hline
\end{tabular}

This Implementation Plan for the MPR1 begins the review process outlined above.

\section{Purpose of MPR1}

This review will be conducted to answer the following fundamental questions about JASPER facility and operations before executing surrogate-material experiments:

- Was the facility construction accomplished per the approved designs?

- Can the systems be operated safely?

- Will the systems be operated, maintained, and supported by trained and competent personnel?

- Are the systems designed to, and will they be operated in conformance with the applicable DOE and other regulatory requirements as promulgated by the LLNL ES\&H Manual?

- Will the systems be operated so that there is no undue risk to employees, the public, and the environment?

- Are all the above properly and adequately documented?

The JASPER MPR 1 will verify that the necessary approved requirements documentation is in place and that the procedures, personnel, equipment, and systems support the approved requirements. 


\section{Scope}

This review will address plant and equipment (hardware) readiness; management and personnel readiness; and management programs (procedures, plans, etc.) readiness.

- Plant and equipment (hardware) readiness: The review will address all NTS Area-27 facilities and systerns that are in relevant to the execution of JASPER dynamic experiments using surrogate-material targets.

- Management and personnel readiness: The review will assess the training and qualification of all facility and operational staff for this phase of the JASPER program.

- Management programs (procedures, plans, etc.) readiness: All management programs for establishing and maintaining the facility as well as those for experiment execution will be assured to be effective and in place.

The MPR is not intended to be an in-depth technical review of the subject areas. That level of review and approval will have been completed before the MPR. Rather, the MPR will affirm that the appropriate approved systems are in place for safe operation. However, should the MPR team question the effectiveness of previous reviews, or find deficiencies in the review process, it may require a more thorough demonstration of system readiness in those specific areas.

\section{Review Prerequisites}

Review prerequisites include completion or acceptance of the following:

- System integration tests.

- Facility Activity Agreement.

- Phase II Operations Operational Safety Plan (OSP) and Integration Work Sheet (IWS).

- DOE/NV Real Estate/ Operations Permit (REOP).

The MPR will be part of the process for completing requirements for Phase III operations: firing the gun for the surrogate experiments.

\section{Overall Approach}

\section{$5.1 \quad$ General}

In preparation for the official review sessions, the project team representative will provide the Team Leader with project documentation as requested. A list of project documents is provided in Appendix A, "Review Document List." This will be addressed with the Team Leader, who will make appropriate accommodations. 
Individual team members will be assigned primary responsibility for specific portions of the review on the basis of their area of expertise. Each will preside over his/her portion of the review and will write that part of the final report in accordance with the JASPER MPR1 schedule.

\subsection{Meetings}

MPR Team meetings will be conducted throughout the JASPER MPR1 period. The Team Leader will call these meetings as required.

The review start date is scheduled for October 18, 2000. The MPR will be conducted over a period of approximately two weeks. The initial meeting will provide an overview of the project, including the technical requirements, experiments to be conducted, facilities, gun operations, and documentation. A comprehensive discussion of recognized hazards is expected. The team will then witness a demonstration of system operations to be executed by JASPER personnel as the final steps of their systems integration phase of the start-up process. Additional meetings with the team and the project staff will be called as required by the Team Leader. However, individual team members will schedule their own dry runs, interviews, and meetings as needed to accomplish their objectives.

\subsection{Findings}

Each finding will be evaluated by the team to determine if it must be addressed and issues corrected prior to JASPER operation. The findings will therefore be categorized as either pre-start or post-start. All findings will be entered into the JASPER document database for tracking purposes by the project.

The N Program Leader will review the final report and give direction to the project and/or facility management to address specific findings that must be closed prior to JASPER operation.

When the pre-start findings have been resolved by the project and/or facility management, their status will be reviewed by the team for confirmation. The team will issue a formal confirmation to the $\mathrm{N}$ Program Leader that the findings are closed.

The review team may generate a list of recommendations for the project. The project team is not required to formally address recommendations

\section{Review Preparations}

For unescorted access to the JASPER facility, review team members must complete JASPER General Employee Training (GET) and General Employee Radiological Training (GERT). Escorts will be provided for those without those prerequisites. 


\section{Programmatic Review Process}

\subsection{JASPER Elements Subject to Review}

The JASPER team will describe their readiness to conduct surrogate-material experiments following the planned sequence of operations. They will base their presentation on the criteria in Section 7.2.

- Transportation and loading/unloading operations for target assemblies, high explosives, and propellant.

- Standby mode:

- Planning (prealign exact constraints).

- Pre-target-arrival gun preparation (prepare launch tube, prepare pump tube, ble acceleration reservoir (AR), prepare propellant charge).

- Diagnostics preparation, including target pins.

- Arming and firing preparation (optical beam breaks, flash $\mathrm{x}$-rays, ultrafast closure system (UCVS), and gun firesets).

- Onsite primary target chamber (PTC) assembly operations (assemble PTC in Building 5180, move PTC from Building 5180 to 5100, install PTC in Building 5100).

- Post-target-arrival gun preparation (move launch tube into firing position, install projectile, install AR).

- Post-target-arrival diagnostic preparation (align PTC, install FXR film, prepare FXR, OBB, continuous-wave X-ray).

- Pre-shot mode:

- PTC and SCC to vacuum (button-up PTC/SCC, pull vacuum on PTC, pull vacuum on $\mathrm{SCC}$ ).

- Final gun room preparation (perform pump tube pressure test, perform final gun room preparation, load propellant).

- Diagnostics preparation.

- Shot mode:

- Arming and firing (pressurize pump tube with drive gas, prepare FXR final shot configuration, backfill lines, arm firesets, fire JASPER gun).

- Post-shot mode:

- PTC and SCC safing (perform SCC hydrogen fast fill and slow purge, purge UCVS vent volume, fill and purge PTC with argon). 
- Reentry into gun room (vent the pump tube, reenter gun room).

- Reentry into SCC post-shot.

$\because$ Cleanup operations (remove PTC).

- Standby mode:

- SCC door operations (open or shut SCC door).

In addition to those technical operations, the review will cover the following project administrative functions:

- Facility maintenance and upgrades, including functional test procedures.

- Project document review and approval process.

- System integration.

- Manpower training, including technical qualifications.

- Technical reviews of components, action items generated, and the formal closure of those action items.

- Configuration management.

- Conduct of operations.

- Abnormal environments and emergency response procedures.

The administrative functions must demonstrate compliance with the LLNL ES\&H Manual and appropriate NV Directives.

\subsection{Criteria for Review}

For each work activity, the Team will assure Integrated Safety Management Principles and Functions are incorporated as appropriate. The project team must demonstrate:

- A documented safety chain of responsibility exists from the Laboratory Director and/or DOE/NV Manager to each worker, and that the safety responsibilities and reporting procedures are understood at all levels.

- Management and safety roles, responsibilities, and authorities for organizations and individuals are clearly defined, documented, and understood. The LLNL position as JASPER "safety coordinator" must be clear.

- Individuals with proper skills, knowledge, and abilities are further qualified through ISMS training and job-specific training required by the JASPER project.

- The work activity is defined in a manner that allows it to be properly analyzed, controlled, performed, and monitored. 
- ES\&H requirements are funded adequately to assure safety of activity execution.

- Hazards are identified and analyzed using appropriate sections of the LLNL ES\&H Manual; they are summarized in the Integration Work Sheet (IWS) for the operation.

- Controls are developed and implemented using requirements described in the ES\&H Manual.

- Appropriate safety standards and requirements from the Laboratory's Work Smart Standards set are used as described in the ES\&H Manual.

- Controls appropriate to the hazard level, following ES\&H Manual requirements, are applied to the work.

- Formal review and authorization procedures are in place and understood. The authorization roles and responsibilities of each participating organization at each level must be documented.

- Work is conducted under applicable procedures and governing documents.

- Work is monitored, safety assessments are conducted and acted upon, and an effective lessons-learned process is in place.

- The administrative operations must demonstrate compliance with the LLNL ES\&H Manual and appropriate NV Directives. 


\section{Administration}

The review team will be provided with access to the relevant documents as described above. Team member individual areas of responsibility are summarized below for quick reference.

\begin{tabular}{|l|l|}
\hline \multicolumn{1}{|c|}{$\begin{array}{c}\text { Team member (primary } \\
\text { reviewer) }\end{array}$} & \multicolumn{1}{|c|}{ Area of expertise } \\
\hline Wilson Cooper & Team Leader \\
\hline Tony Davito; Wendell Moen & Mechanical Engineering \\
\hline $\begin{array}{l}\text { Gordon Krauter; Terry } \\
\text { Rossow }\end{array}$ & Electronics Engineering \\
\hline Harold Roberts & Arming and Firing \\
\hline Ross Wilson & ES\&H \\
\hline Dennis Shampine & Gun Operations \\
\hline Rick Higgs & NV Interfaces \\
\hline Dan Loney & Facility Systems \\
\hline
\end{tabular}

The Team Leader will arrange meetings to discuss expectations, issues, findings, and conclusions. Project personnel should be available to provide quick access for clarifications and requested information. The Team Leader will adjudicate any interface concerns between the review team and project personnel. A final review report will be issued with a final list of action items and conclusions. Participation of DOE oversight personnel is both expected and desired throughout the review process; however, all review management will be through the Team Leader to N Program Management.

\section{Reporting and Resolutions}

The final report will include all reviewed areas and the corresponding conclusion of the team. Action items will be presented in a prioritized list on the basis of requirements for resolution before work authorization is granted. The project personnel will generate a separate report detailing their response to action items. Proposed resolutions of all action items will be documented in the response report. 


\section{Schedule}

The formal review start date is currently scheduled for October 18,2000 . The duration should be approximately two calendar weeks. Closure of findings is expected to be completed within the following two weeks. See summarized schedule below:

\begin{tabular}{|c|l|}
\hline Date & \multicolumn{1}{|c|}{ Activity } \\
\hline $10 / 9$ & $\begin{array}{l}\text { JASPER MPR1 Team meeting to discuss draft Implementation Plan, assign } \\
\text { responsibilities, and confirm Appendix A requirements. }\end{array}$ \\
\hline $10 / 9$ & Required review documents submitted by Project Management to Team Leader. \\
\hline $10 / 18$ & Review start date. \\
\hline $10 / 27$ & Review closeout briefing by Team to Project Management. \\
\hline $11 / 10$ & Final Review Report submitted to N Program Management. \\
\hline
\end{tabular}

Other meetings will be conducted as required throughout the review process. 


\section{Appendix A. Review Documentation List}

\section{A.1 Operational Plans}

\begin{tabular}{|l|l|l|}
\hline \multicolumn{1}{|c|}{ Doc. No. } & \multicolumn{1}{|c|}{ Title } & \multicolumn{1}{c|}{ Lead } \\
\hline JAS-PLN-01 & Facility Safety Plan (FSP) & LLNL/ McElroy \\
\hline JAS-PLN-02 & Quality Assurance Program Plan & BN/ Doney \\
\hline JAS-PLN-03 & Configuration Management Plan & LLNL/ Miller \\
\hline JAS-PLN-04 & Waste Management Plan & BN/ Griffin/Cruz \\
\hline JAS-PLN-05 & Security Plan & LLNL/ Williams \\
\hline JAS-PLN-06 & Training and Qualification Plan & BN/Doney \\
\hline JAS-PLN-07 & Emergency Response Procedure & BN/ Wehrly \\
\hline JAS-PLN-08 & Conduct of Operations Plan & BN/ Doney \\
\hline JAS-PLN-09 & Computer Security Plan & SNL/ French \\
\hline JAS-PLN-10 & Start-up Plan & LLNL/ Pratuch \\
\hline JAS-PLN-11 & Maintenance Plan & LLNL/ Miller \\
\hline OSP-N-144 & Operational Safety Plan for Phase II Testing & LLNL/ McElroy \\
\hline
\end{tabular}




\section{A.2 Technical Operating Procedures}

\begin{tabular}{|c|c|c|}
\hline Doc. No. & Title & Lead \\
\hline JAS-PRC-TO-01 & (Deleted) & \\
\hline JAS-PRC-TO-02 & (Deleted) & \\
\hline JAS-PRC-TO-03 & PTC Removal and Staging in WAA & LLNL Dittman \\
\hline JAS-PRC-TO-04 & Assembly of PTC & LLNL/ Pratuch \\
\hline JAS-PRC-TO-05 & Pressure and Leak Check of PTC & LLNL/ Pratuch \\
\hline JAS-PRC-TO-06 & $\begin{array}{l}\text { Transportation and Installation of PTC into } \\
\text { SCC }\end{array}$ & LLNL Dittman \\
\hline JAS-PRC-TO-07 & Target Alignment & LLNL Abdallah \\
\hline JAS-PRC-TO-08 & Target Assembly & LLNL/ Abdallah \\
\hline JAS-PRC-TO-09 & (Deleted) & \\
\hline JAS-PRC-TO-10 & Diagnostics Planning and Integration & BN/ Whitcomb \\
\hline JAS-PRC-TO-11 & (Deleted) & \\
\hline JAS-PRC-TO-12 & Run/Safe and Sweep Procedures & LLNL/Montelongo \\
\hline JAS-PRC-TO-13 & (Deleted) & \\
\hline JAS-PRC-TO-14 & $\begin{array}{l}\text { Control System Power Outage Recovery } \\
\text { Procedure }\end{array}$ & LLNL/Montelongo \\
\hline JAS-PRC-TO-15 & Control System Quarterly Functional Checks & BN/Baker \\
\hline JAS-PRC-TO-16 & SCC Button-Up Activities & LLNL/ Pratuch \\
\hline JAS-PRC-TO-17 & Gas Gun Assembly/Disassembly Procedure & BN/ Konrad \\
\hline JAS-PRC-TO-18 & $\begin{array}{l}\text { Pump Tube Preparation and Leak } \\
\text { Check/Piston Loading }\end{array}$ & LLNL/ Hinsey \\
\hline JAS-PRC-TO-19 & Breech Preparation and Gun Loading & LLNL/ Hinsey \\
\hline JAS-PRC-TO-20 & UCV Timing and Firing System Setup & LLNL / Weirup \\
\hline JAS-PRC-TO-21 & Propellant Charge Preparation & LLNL/ Hinsey \\
\hline JAS-PRC-TO-22 & Firing Sequence Operations & LLNL/ Hinsey \\
\hline JAS-PRC-TO-23 & Misfire Procedure & LLNL/Hinsey \\
\hline JAS-PRC-TO-24 & Gun Room Reentry and Gun Safing & LLNL/ Hinsey \\
\hline JAS-PRC-TO-25 & SCC Reentry and Turnover & LANL / Van Cleave \\
\hline JAS-PRC-TO-26 & Control System Shutdown & LLNL/Montelongo \\
\hline JAS-PRC-TO-27 & Execution Procedure & LLNL/Miller \\
\hline JAS-PRC-TO-28 & PTC Waste Packaging & BN/ Cruz \\
\hline
\end{tabular}




\section{A.3 Administrative Procedures}

\begin{tabular}{|c|l|l|}
\hline \multicolumn{1}{|c|}{ Doc. No. } & \multicolumn{1}{|c|}{ Title } & \multicolumn{1}{c|}{ Lead } \\
\hline JAS-PRC-AD-01 & $\begin{array}{l}\text { Preparation Guide for JASPER Plans and } \\
\text { Procedures }\end{array}$ & LLNL/McElroy \\
\hline JAS-PRC-AD-02 & Formal Design Review Guidelines & LLNL/ Valk \\
\hline JAS-PRC-AD-03 & Functional Tracking System & LLNL/ Midtun \\
\hline JAS-PRC-AD-04 & Document Control & LLNL/ Butler \\
\hline JAS-PRC-AD-05 & Change Control & LLNL/ Miller \\
\hline JAS-PRC-AD-06 & Self-Assessment Program & BN/ Doney \\
\hline JAS-PRC-AD-07 & Key and Lock Control & LLNL/ Butler \\
\hline JAS-PRC-AD-08 & Control of Nonconformances & LLNL/ Doney \\
\hline JAS-PRC-AD-09 & Project Documentation & LLNL/ Doney \\
\hline
\end{tabular}




\section{A.4 System Design Descriptions}

\begin{tabular}{|l|l|l|}
\hline \multicolumn{1}{|c|}{ Doc. No. } & \multicolumn{1}{|c|}{ Lead } \\
\hline JAS-SDD-01 & Control System & LLNL/ Montelongo \\
\hline JAS-SDD-02 & Electrical Distribution System & BN/ Dumas \\
\hline JAS-SDD-03 & UCV Trigger System & LLNL/ Weirup \\
\hline JAS-SDD-04 & Fire Protection & BN/ Svab \\
\hline JAS-SDD-05 & Gas Gun & BN/ Cruz \\
\hline JAS-SDD-06 & Gas Supply System & BN/ Cruz \\
\hline JAS-SDD-07 & Grounding System & BN/ Dumas \\
\hline JAS-SDD-08 & HVAC System & BN/ LaRoy \\
\hline JAS-SDD-09 & Hydrogen Gas Detection System & BN/ LaRoy \\
\hline JAS-SDD-10 & Lightning Protection & BN/ Dumas \\
\hline JAS-SDD-11 & Radiation Monitoring and Detection System & LANL Van Cleave \\
\hline JAS-SDD-12 & Oxygen Monitoring System & BN/ LaRoy \\
\hline JAS-SDD-13 & Primary Target Chamber & LLNU/ Pratuch \\
\hline JAS-SDD-14 & PTC Installation Hardware & LLNL Dittman \\
\hline JAS-SDD-15 & Secondary Containment Chamber & BN/ Sinagra \\
\hline JAS-SDD-16 & Structure & BN/ Sahni \\
\hline JAS-SDD-17 & Vacuum and Vent System & BN/ Cruz \\
\hline JAS-SDD-18 & Contamination Control System & LANU Van Cleave \\
\hline JAS-SDD-19 & Optical Beam Reflectance Sensors & BN/ Whitcomb \\
\hline JAS-SDD-20 & Alignment System & LLNL Abdallah \\
\hline JAS-SDD-21 & Flash X-Ray Sensor System & BN/ Whitcomb \\
\hline JAS-SDD-22 & Continuous X-Ray Sensor System & BN/ Whitcomb \\
\hline JAS-SDD-23 & Compressed Air System & BN/ Cruz \\
\hline JAS-SDD-24 & Gun Firing System & LLNL/ Valk \\
\hline JAS-SDD-25 & Optical Beam Break Sensors & BN Whitcomb \\
\hline
\end{tabular}

